\title{
NITROUS OXIDE EMISSION AND PRODUCTION PATHWAYS UNDER ALTERNATE WETTING-DRYING CONDITIONS IN RICE PADDY SOILS
}

\author{
ABID, A. A. ${ }^{1}-$ ZHANG, $.^{1,2^{*}}-$ AfZAL, M. ${ }^{1}-$ DI, H. ${ }^{1}$ \\ ${ }^{\text {I}}$ Zhejiang Provincial Key Laboratory of Agricultural Resources and Environment, Key \\ Laboratory of Environment Remediation and Ecological Health, Ministry of Education, \\ Zhejiang University, Hangzhou 310058, P. R. China \\ ${ }^{2}$ College of Environmental and Resource Sciences, Zhejiang University, \\ Hangzhou, 310058, P. R. China \\ *Corresponding author \\ e-mail: qczhang@zju.edu.cn; phone:+86-571-8898-2413 \\ (Received $5^{\text {th }}$ May 2019; accepted $28^{\text {th }}$ Aug 2019)
}

\begin{abstract}
The aim of this study was to evaluate the relative contributions of nitrification and denitrification in rice paddy soils under various water events. A laboratory incubation study was conducted in China to quantify $\mathrm{N}_{2} \mathrm{O}$ production during alternate wetting and drying cycle (AWD) versus permanent flooding $(\mathrm{PF})$. The soils were treated with long-term chemical fertilizer (CF); chemical fertilizer plus pig manure (PMCF); and chemical fertilizer plus rice straw (SRCF) for 5 years. The results showed that $\mathrm{N}_{2} \mathrm{O}$ flux during AWD was consistently higher than PF. The highest $\mathrm{N}_{2} \mathrm{O}$ flux during AWD was $1.94 \mathrm{mg} \mathrm{m}^{-2} \mathrm{~h}^{-1}$. The PMCF and SRCF soils had higher $\mathrm{N}_{2} \mathrm{O}$ emissions compared to CF and CK soils. Ammonia oxidizer community peaks were found at $60 \%$ field capacity (FC) $(\mathrm{p}<0.0001)$, while, for denitrifier, this increase was maintained for a certain period of time (10d) and then started to decrease. Autotrophic nitrification appeared to be an important and dominant process of $\mathrm{N}_{2} \mathrm{O}$ emissions during AWD and PF, contributed $79.03 \%$ of $\mathrm{N}_{2} \mathrm{O}$ emissions during AWD, while $36.53 \%$ during PF. Thus, the results concluded that under AWD event the addition of pig manure and rice straw plus chemical fertilizer significantly increased the $\mathrm{N}_{2} \mathrm{O}$ flux, by stimulating the growth of microbial communities.
\end{abstract}

Keywords: $\mathrm{N}_{2} \mathrm{O}$, flux, water events, pig manure, rice straw, ${ }^{15} \mathrm{~N}$ stable isotopes

\section{Introduction}

Ecosystems are adversely affected by the global warming if actions to mitigate it are not taken. Besides industrial emissions, biological processes can also contribute to the greenhouse gas emissions ( $\mathrm{GHG}$ ), especially nitrous oxide $\left(\mathrm{N}_{2} \mathrm{O}\right) \cdot \mathrm{N}_{2} \mathrm{O}$ is an important greenhouse gas and its concentration in the atmosphere is comparatively lower than $\mathrm{CO}_{2}$ concentration but its global warming potentials (GWP) is relatively 265 times higher over 100 years than that of $\mathrm{CO}_{2}$ (IPCC, 2013). Agricultural soils contribute about $60 \%$ to anthropogenic $\mathrm{N}_{2} \mathrm{O}$ emissions which is mainly due to fertilizer application (Charles et al., 2017; Liu et al., 2017). Fertilization of agricultural soils is considered to be an important source of $\mathrm{N}_{2} \mathrm{O}$ emissions, which contributes about $13-24 \%$ of annual emissions (IPCC, 2007). Among these agricultural soils, rice paddy soils are considered to be a main source of $\mathrm{N}_{2} \mathrm{O}$ emissions. Rice is a staple food for half of the world's population and approximately 155 million ha. is grown annually, around the globe (Abid et al., 2018).

Alternating wetting and drying (AWD) practice is a common practice which is being used to save water in rice fields. AWD reduce water use by $23-33 \%$ in rice paddy soils (Carrijo et al., 2017). It has been used in many countries such as Philippines (Belder et 
al., 2004), China (Cabangon et al., 2004) and Japan (Chapagain and Yamaji, 2010). The AWD practice has been found to give higher or equal rice yield (Zhang et al., 2009) compared to conventional practice, i.e. continuous flooding practice, where surplus of $\mathrm{N}_{2} \mathrm{O}$ is produced during this process (Peng et al., 2011). However, the underlying causes, e.g. microbial mechanisms of $\mathrm{N}_{2} \mathrm{O}$ emissions are generally unknown.

Nitrous oxide is mainly emitted by nitrification and denitrification processes (Wrage et al., 2001), and both processes may occur in soil simultaneously (Abbasi and Adams, 2000; Garrido et al., 2002; Webster and Hopkins, 1996). To what extent each of these processes contributes to the $\mathrm{N}_{2} \mathrm{O}$ emissions in the rice during $\mathrm{AWD}$ and permanent flooding (PF) are not fully understood. This is mainly attributed to oxygen content of the soil, and further estimation of water filled pore space (WFPS) has been considered as a major influencing factor. Nitrogen stable isotopes with acetylene $\left(\mathrm{C}_{2} \mathrm{H}_{2}\right)$ can offer a precise information about nitrogen cycle in ecosystems (Ostrom et al., 2002). It is of interest to use ${ }^{15} \mathrm{~N}$ as a tracer because a negligible isotope fractionation is being used as a tracer during biological processes. Acetylene $\left(\mathrm{C}_{2} \mathrm{H}_{2}\right)$ inhibits $\mathrm{NH}_{3}{ }^{+}$oxidation at low concentration $(10 \mathrm{~Pa})$ and start to inhibit $\mathrm{N}_{2} \mathrm{O}$ reductase at high concentration $(10 \mathrm{kPa})$ during denitrification (Berg et al., 1982). Also, $\mathrm{C}_{2} \mathrm{H}_{2}$ may inhibit $\mathrm{NH}_{4}{ }^{+}$oxidation by autotrophs but inhibition by heterotrophic nitrifiers is not documented (Moir et al., 1996; Hynes and Knowles, 1982; Daum et al., 1998). Recently, stable isotope signatures coupled with $\mathrm{C}_{2} \mathrm{H}_{2}(10 \mathrm{~Pa} ; 0.01 \% \mathrm{v} / \mathrm{v})$ are being used to estimate $\mathrm{N}_{2} \mathrm{O}$ source and relative contributions of denitrification, heterotrophic nitrification and autotrophic nitrification processes in soil (Baggs et al., 2003; Stevens et al., 1997).

The obvious benefits of implementing AWD strategy are to save irrigation water and reduce $\mathrm{CH}_{4}$ emissions. On the other hand, the combined effect of long term fertilization and AWD on $\mathrm{N}_{2} \mathrm{O}$ is still inconclusive. Also, the $\mathrm{N}_{2} \mathrm{O}$ production source during AWD and PF events is still poorly understood. Therefore, the objectives of the present study were: (1) to determine the potential of AWD to produce $\mathrm{N}_{2} \mathrm{O}$ from rice paddies as compared to the normal practice of rice (PF); (2) to determine the effect of long term organic (PMCF, SRCF) and inorganic (CF) fertilizers along with different water events (AWD, PF) on $\mathrm{N}_{2} \mathrm{O}$ gas emissions; and (3) to quantify the contribution of different processes (nitrification, denitrification) to $\mathrm{N}_{2} \mathrm{O}$ emissions under AWD and PF related to long term fertilization, using ${ }^{15} \mathrm{~N}$ stable isotopes in combination with $\mathrm{C}_{2} \mathrm{H}_{2}$.

\section{Materials and methods}

\section{Soil sampling site}

A long-term fertilized experiment (LTFE) was conducted from 2010 to 2014 and soil samples were collected. This site was located in Jintan county, Jiangsu province, China $\left(120^{\circ} 0^{\prime} 41^{\prime \prime}\right.$ East, $29^{\circ} 57^{\prime}$ 9" North). The annual mean precipitation and temperature of study area are $1452.5 \mathrm{~mm}$ and $16.27^{\circ} \mathrm{C}$, respectively. A rice paddy field was selected with 5-yr canola-rice rotation history. The soil samples were grouped into four treatment groups, including no fertilization $(\mathrm{CK}), 100 \%$ chemical fertilization (CF: $\mathrm{N}$ $\left.314 \mathrm{~kg} \mathrm{ha}^{-1}, \mathrm{P}_{2} \mathrm{O}_{5} 31.5 \mathrm{~kg} \mathrm{ha}^{-1}, \mathrm{~K}_{2} \mathrm{O} 153 \mathrm{~kg} \mathrm{ha}^{-1}\right)$, pig manure compost plus $50 \%$ chemical fertilization (PMCF: Pig manure $6000 \mathrm{~kg} \mathrm{ha}^{-1}+\mathrm{N} 157 \mathrm{~kg} \mathrm{hm}^{-2}, \mathrm{P}_{2} \mathrm{O}_{5}$ $31.5 \mathrm{~kg} \mathrm{ha}^{-1}, \mathrm{~K}_{2} \mathrm{O} 153 \mathrm{~kg} \mathrm{ha}^{-1}$ ) and rice straw plus $50 \%$ chemical fertilization (SRCF: rice straw $6000 \mathrm{~kg} \mathrm{ha}^{-1}+\mathrm{N} 157 \mathrm{~kg} \mathrm{ha}^{-1}, \mathrm{P}_{2} \mathrm{O}_{5} 31.5 \mathrm{~kg} \mathrm{ha}^{-1}, \mathrm{~K}_{2} \mathrm{O} 153 \mathrm{~kg} \mathrm{ha}^{-1}$ ). Just after the rice harvested in 2014, five soil cores were collected at a depth of $15 \mathrm{~cm}$ from three replicates of each treatment and five hundred grams of soils were packed. The soil cores 
were put in sterile plastic bags, zipped and transported to the laboratory and stored at $4{ }^{\circ} \mathrm{C}$. Each replicated sample was divided and one sub sample was air-dried and sieved through a $2.0 \mathrm{~mm}$ for subsequent chemical analysis and another sub sample was incubated under different dry and wet conditions.

\section{Incubation design}

The incubation was carried out at $25{ }^{\circ} \mathrm{C}$ with two water events including: (a) alternating with 7 days continuous flooding followed by 7 days of air-drying (AWD); (b) permanent flooding for 14 days (PF). The detailed methodology of the incubation experiment was as follows (Fig. 1). Two hundred g of soil collected from CK, CF, PMCF and SRCF treatments were put in $1000 \mathrm{~mL}$ glass pots and to make flooding conditions additional water was added. For AWD, soils were incubated as flooded for 7 days, with gas and soil samples were collected after 1 and 7 days of flooding incubation $(100 \% \mathrm{FC}, 1 \mathrm{~d} ; 100 \% \mathrm{FC}, 7 \mathrm{~d})$. Then the water was removed to reach $80 \%$ field capacity $(80 \% \mathrm{FC}, 10 \mathrm{~d})$ and $60 \%$ field capacity $(60 \% \mathrm{FC}, 14 \mathrm{~d})$, samples were also collected at $80 \% \mathrm{FC}, 10 \mathrm{~d}$ and $60 \% \mathrm{FC}, 14 \mathrm{~d}$ ). For PF, the same treatments were incubated with flooded conditions for $14 \mathrm{~d}$ and gas and soil samples were collected after 1, 7, 10 and $14 \mathrm{~d}$. Headspace gas samples were collected after 1, 7, 10 and $14 \mathrm{~d}$ immediately after closing the jars and 30 min later using a hypodermic needle and a polypropylene syringe. These gas samples were used to analyze the isotopic ${ }^{15} \mathrm{~N}-\mathrm{N}_{2} \mathrm{O}$. $\mathrm{N}_{2} \mathrm{O}$ was calculated using GC 2010 plus (Shimadzu).

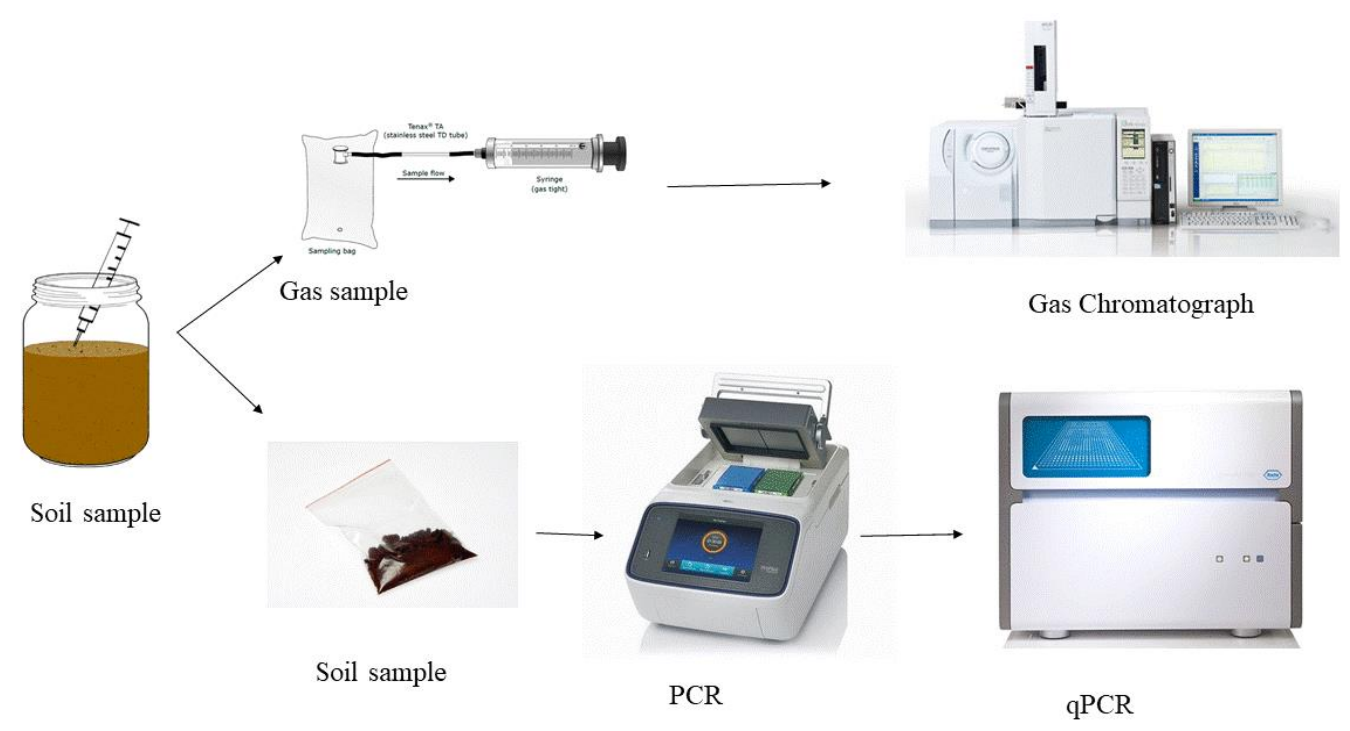

Figure 1. Schematic diagram of whole study plan

After 14 days of incubation, all soils were treated with (a) ${ }^{14} \mathrm{NH}_{4}{ }^{15} \mathrm{NO}_{3}$, (b) ${ }^{15} \mathrm{NH}_{4}{ }^{15} \mathrm{NO}_{3}$, (c) ${ }^{15} \mathrm{NH}_{4}{ }^{15} \mathrm{NO}_{3}+\mathrm{C}_{2} \mathrm{H}_{2}(0.01 \% \mathrm{v} / \mathrm{v})$, and (d) no $\mathrm{N}$ addition. ${ }^{14+15} \mathrm{~N}$ was applied at $200 \mathrm{mg}$ total $\mathrm{N} \mathrm{m}^{-2}\left(20 \%\right.$ atom $\%$ excess $\left.{ }^{15} \mathrm{~N}\right)$ combined with $\mathrm{C}_{2} \mathrm{H}_{2}(10 \mathrm{~Pa})$ (Table 1). Additional water was added to achieve the desired moisture contents (flooding). Also, three replicates of each treatment was created for gas analyses. To create gas-tight incubations, the lids of the jars were then closed. Five $\mathrm{ml}(1 \% \mathrm{v} / \mathrm{v}$ in air) of $\mathrm{C}_{2} \mathrm{H}_{2}$ gas was injected to the headspace of a further three replicates of the ${ }^{15} \mathrm{NH}_{4}{ }^{15} \mathrm{NO}_{3}$ fertilizer treatments (treatment c) (Table 1) to make a final concentration of 
$0.01 \%(\mathrm{v} / \mathrm{v})$ which was considered sufficient to inhibit oxidation of $\mathrm{NH}_{3}{ }^{+}$(Bateman and Baggs, 2005). Five days after fertilizer additions, the jars were opened because inhibition continued for about 3 days after $0.01 \%(\mathrm{v} / \mathrm{v}) \mathrm{C}_{2} \mathrm{H}_{2}$ addition, and there was no effect of jars opening on trace gas production (Bateman and Baggs, 2005). Seven days after fertilizer addition, $20 \mathrm{ml}$ gas samples were collected at 0 and $30 \mathrm{~min}$ after closing the glass jars from each treatment using poly-pyrine syringe. The ${ }^{15} \mathrm{~N}$ was analyzed using isotope ratio mass spectrometer (Europa PDZ 20:20).

Table 1. Outline of the ${ }^{15} \mathrm{~N}$ fertilizer and $\mathrm{C}_{2} \mathrm{H}_{2}$ inhibition treatments used to estimate the contribution of denitrification and autotrophic and heterotrophic nitrification to ${ }^{15} \mathrm{~N}-\mathrm{N}_{2} \mathrm{O}$ emissions

\begin{tabular}{c|c}
\hline Treatment & Source of ${ }^{\mathbf{1 5}} \mathbf{N}-\mathbf{N}_{2} \mathbf{O}$ \\
\hline (a) ${ }^{14} \mathrm{NH}_{4}{ }^{15} \mathrm{NO}_{3}$ & Denitrification \\
(b) ${ }^{15} \mathrm{NH}_{4}{ }^{15} \mathrm{NO}_{3}$ & Denitrification and nitrification (autotrophic and heterotrophic) \\
(c) ${ }^{15} \mathrm{NH}_{4}{ }_{4}^{15} \mathrm{NO}_{3}+\mathrm{C}_{2} \mathrm{H}_{2}(0.01 \% \mathrm{v} / \mathrm{v})$ & Denitrification and heterotrophic nitrification \\
(d) (c) minus (a) & Heterotrophic nitrification \\
\hline
\end{tabular}

\section{q-PCR to determine the abundance of nitrifiers and denitrifiers}

After 1, 7, 10 and $14 \mathrm{~d}$ of different water application, soil samples were collected and $0.5 \mathrm{~g}$ sampled soil was used to extract DNA using TAKARA DNA standard protocol. Nano drop technology was also used to quantify DNA (Nano Drop Technologies, Wilmington, DE, USA). Real time quantitative PCR was used to quantify the abundance of denitrifier (nirS, nirK) and nitrifier (AOA amoA, AOB amoA) communities. Serial dilutions of linearized plasmids were used to produce standard curves by using cloned $\mathrm{AOA}, \mathrm{AOB}$, nirS and nirK genes amplified from denitrifying and nitrifying strains. The cloning kit (V007 TsingKe China) was used to prepare standard (www.tsingke.net). The qPCR primers sets used to target desired genes are indicated in Table 2. A reaction mixture of $20 \mu \mathrm{L}$ containing $1 \mu \mathrm{L}$ target gene primer, SYBR Premix $10 \mu \mathrm{L}$, total DNA template $1 \mu \mathrm{L}$, and deionized distilled water to make final volume $20 \mu \mathrm{L}$. The copy number of these plasmids was directly calculated based on the concentrations and lengths (base pairs) of them. The copy number of the target genes in unknown soil DNA were analyzed by comparing with their reactive standard curves.

Table 2. Real-time PCR primer sets, conditions of the assay

\begin{tabular}{|c|c|c|c|c|c|}
\hline \multicolumn{2}{|c|}{ Target gene base pairs } & \multirow{2}{*}{$\begin{array}{c}\text { Primer } \\
\text { amoA-1F } \\
\text { amoA-2R }\end{array}$} & \multirow{2}{*}{$\begin{array}{c}\text { Nucleotide sequence }\left(\mathbf{5}^{\prime} \text {-3') }\right. \\
\text { GGGGTTTCTACTGGTGGT } \\
\text { CCCCTCKGSAAAGCCTTCTTC }\end{array}$} & \multirow{2}{*}{$\begin{array}{c}\begin{array}{c}\text { Annealing } \\
\text { temperature } \\
\text { and time }\end{array} \\
55^{\circ} \mathrm{C} \text { for } 45 \mathrm{~s} \\
\end{array}$} & \multirow{2}{*}{$\begin{array}{c}\text { Reference } \\
\text { Rotthauwe et al., } 1997\end{array}$} \\
\hline Bacterial amoA & $491 \mathrm{bp}$ & & & & \\
\hline Archaeal amoA & $635 \mathrm{bp}$ & $\begin{array}{l}\text { amoAF } \\
\text { amoAR }\end{array}$ & $\begin{array}{l}\text { STAATGGTCTGGCTTAGACG } \\
\text { GCGGCCATCCATCTGTATGT }\end{array}$ & $53^{\circ} \mathrm{C}$ for $45 \mathrm{~s}$ & Francis et al., 2005 \\
\hline $\operatorname{nirK}$ & $472 \mathrm{bp}$ & $\begin{array}{l}\mathrm{F} 1 \mathrm{aCu} \\
\mathrm{R} 3 \mathrm{Cu}\end{array}$ & $\begin{array}{c}\text { ATCATGGTSCTGCCGCG } \\
\text { GCCTCGATCAGRTTGTGGTT }\end{array}$ & $63^{\circ} \mathrm{C}$ for $30 \mathrm{~s}$ & Hallin and Lindgren, 1999 \\
\hline $\operatorname{nirS}$ & $425 \mathrm{bp}$ & $\begin{array}{l}\mathrm{Cd} 3 \mathrm{aF} \\
\mathrm{R} 3 \mathrm{Cd}\end{array}$ & $\begin{array}{l}\text { GTSAACGTSAAGGARACSGG } \\
\text { GASTTCGGRTGSGTCTCTTGA }\end{array}$ & $57^{\circ} \mathrm{C}$ for $30 \mathrm{~s}$ & Throbäck et al., 2004 \\
\hline
\end{tabular}




\section{Statistical analysis}

SPSS 16.0 package was used to perform all statistical (SPSS, Chicago, IL, USA). One way analysis of variance (ANOVA) test was used to analyze significant differences among different treatments. ANOVA, followed by the least significant difference (LSD) test, in which $P<0.05$ was considered statistically significant. Also, Duncan's Multiple Range Test was used to determine significant mean differences. Correlation analysis was performed to analyze the correlation between variables. All results were accepted at significant probability 0.05 .

\section{Results}

\section{$\mathrm{N}_{2} \mathrm{O}$ gas emission}

Nitrous oxide $\left(\mathrm{N}_{2} \mathrm{O}\right)$ fluxes of the incubated soils showed different trends during AWD and PF events (Fig. 2). $\mathrm{N}_{2} \mathrm{O}$ flux increased with reducing moisture contents over time during AWD. $\mathrm{N}_{2} \mathrm{O}$ emitted over 14 days $(60 \% \mathrm{FC})$ was significantly higher $(P<0.001)$ throughout the experiment during AWD than PF. While comparing fertilizer treatments, the highest emissions were recorded from SRCF $\left(1.88 \mathrm{mg} \mathrm{m}^{-2} \mathrm{~h}^{-1}\right)$ and PMCF (1.34 mg m $\mathrm{m} \mathrm{h}^{-1}$ ) over 14 days, which were 12 and 20 times greater than those over 10 days and 7 days of AWD, respectively. $\mathrm{N}_{2} \mathrm{O}$ emissions from fertilized soils decreased after one day throughout trial period but were greater than unfertilized controls. The highest fluxes were measured at $60 \%$ FC over 14 days. In the CK and CF treatments, $\mathrm{N}_{2} \mathrm{O}$ fluxes were minimal over 1 day which was 0.02 and $0.01 \mathrm{mg} \mathrm{m}^{-2} \mathrm{~h}^{-1}$, while the treatments of PMCF and SRCF showed slightly higher $\mathrm{N}_{2} \mathrm{O}$ emissions, ranging from 0.12 to $0.28 \mathrm{mg} \mathrm{m}^{-2} \mathrm{~h}^{-1}$ with same moisture contents. No significant differences were observed in total $\mathrm{N}_{2} \mathrm{O}$ produced over 1 day and 7 days of flooded conditions. During AWD, the emissions of $\mathrm{N}_{2} \mathrm{O}$ increased when exposed to air-drying conditions after continuous flooding over one week. While During PF, the fluxes significantly decreased with time and the lowest fluxes were measured over 14 days of continuous flooding $(P<0.0001)$.

\section{Sources of $\mathrm{N}_{2} \mathrm{O}$}

Labelling of ${ }^{15} \mathrm{~N}$ is the only way to differentiate $\mathrm{N}$ pool, as a possible substrate for $\mathrm{N}_{2} \mathrm{O}$ production. $\mathrm{N}_{2} \mathrm{O}$ emitted from $\mathrm{C}_{2} \mathrm{H}_{2}$ treatments could be produced either by heterotrophic nitrification or denitrification (treatment c), and ${ }^{15} \mathrm{~N}-\mathrm{N}_{2} \mathrm{O}$ production from ${ }^{14} \mathrm{NH}_{4}{ }^{15} \mathrm{NO}_{3}$ (treatment a) could be produced by denitrification (Table 1). The difference in the emissions of ${ }^{15} \mathrm{~N}-\mathrm{N}_{2} \mathrm{O}$ between the ${ }^{14} \mathrm{NH}_{4}{ }^{15} \mathrm{NO}_{3}$ (treatment a) and ${ }^{15} \mathrm{NH}_{4}{ }^{15} \mathrm{NO}_{3}$ (treatment b) was attributed to nitrification, and the difference in the emissions of ${ }^{15} \mathrm{~N}$ $\mathrm{N}_{2} \mathrm{O}$ between ${ }^{14} \mathrm{NH}_{4}{ }^{15} \mathrm{NO}_{3}$ (treatment a) and ${ }^{15} \mathrm{NH}_{4}{ }^{15} \mathrm{NO}_{3}+\mathrm{C}_{2} \mathrm{H}_{2}$ (treatment c) was used to quantify heterotrophic nitrification. Results of the present study showed relatively higher ${ }^{15} \mathrm{~N}-\mathrm{N}_{2} \mathrm{O}$ emissions were measured during AWD than PF (Fig. 3) but this relation was not significant. The total ${ }^{15} \mathrm{~N}-\mathrm{N}_{2} \mathrm{O}$ emissions were recorded during AWD condition in PMCF and SRCF treatments $\left(0.23,0.24 \mathrm{mg} \mathrm{m}^{-2} \mathrm{~h}^{-1}\right)$, which were significantly higher than $\mathrm{CK}$ and $\mathrm{CF}$ treatments. ${ }^{15} \mathrm{~N}-\mathrm{N}_{2} \mathrm{O}$ emissions during $60 \% \mathrm{FC}$ in the presence of $\mathrm{C}_{2} \mathrm{H}_{2}$ were significantly lower than the other treatments, indicating autotrophic nitrification as main contributor to $\mathrm{N}_{2} \mathrm{O}$ emissions (Table 2). In the presence of $\mathrm{C}_{2} \mathrm{H}_{2}, \mathrm{~N}_{2} \mathrm{O}$ produced was accredited to denitrification and/or heterotrophic nitrification. A strong significant positive correlation was found between autotrophic nitrification nitrous oxide production, 
indicating autotrophic nitrification as a predominant ${ }^{15} \mathrm{~N}-\mathrm{N}_{2} \mathrm{O}$ source during both AWD and $\mathrm{PF}\left(P<0.01, \mathrm{R}^{2}=0.77\right)$ (Table 3; Fig. 4). The maximum $\mathrm{N}_{2} \mathrm{O}$ production from autotrophic nitrification was $0.19 \mathrm{mg} \mathrm{N} \mathrm{m}^{-2} \mathrm{~h}^{-1}$ during AWD. Between 57 and $72 \%$ of $\mathrm{N}_{2} \mathrm{O}$ production during both AWD and PF emitted from autotrophic nitrification in all fertilized treatments and significantly higher compared to $\mathrm{CK}$. The mean ${ }^{15} \mathrm{~N}_{-} \mathrm{N}_{2} \mathrm{O}$ emissions during AWD were $0.89 \mathrm{mg} \mathrm{N} \mathrm{m}^{-2} \mathrm{~h}^{-1}$, contributing $79 \%$ by autotrophic nitrification, while during $\mathrm{PF}$, the $\mathrm{N}_{2} \mathrm{O}$ emissions were $0.13 \mathrm{mg} \mathrm{N} \mathrm{m}^{-2} \mathrm{~h}^{-1}$, and $52 \%$ was contributed by denitrification and $36 \%$ by autotrophic nitrification (Table 4 ).

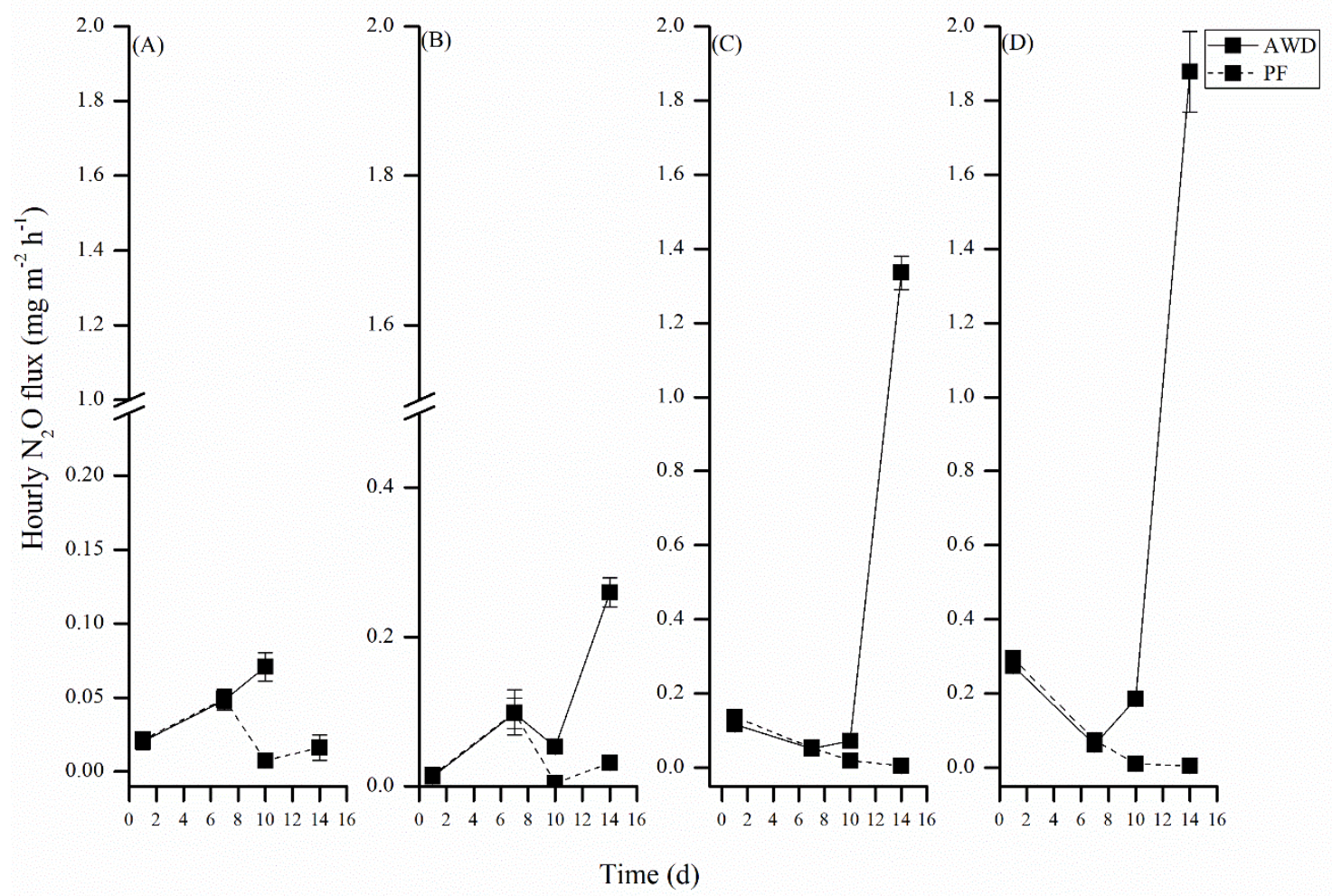

Figure 2. Hourly $\mathrm{N}_{2} \mathrm{O}$ emission $\left(m g \mathrm{~m}^{-2} h^{-1}\right.$ ) from (A) $C K$, (B) $C F$, (C) PMCF and (D) SRCF treatments after 1, 7, 10 and 14 days of different water treatment incubation. AWD represents alternate drying and flooding conditions while PF represents permanent flooding conditions. Arrow bar represents standard deviation. CK: control, CF: Chemical fertilization, PMCF: Pig manure plus chemical fertilizer, SRCF: Rice straw plus chemical fertilizer

Table 3. Correlation of total isotopic ${ }^{15} \mathrm{~N}_{2} \mathrm{O}$ with denitrification, heterotrophic nitrification and autotrophic nitrification $(n=8)$

\begin{tabular}{c|c|c|c|c}
\hline & Total ${ }^{15} \mathbf{N}_{2} \mathbf{O}$ flux & Denitrification & $\begin{array}{c}\text { Heterotrophic } \\
\text { nitrification }\end{array}$ & $\begin{array}{c}\text { Autotrophic } \\
\text { nitrification }\end{array}$ \\
\hline Total ${ }^{15} \mathrm{~N}_{2} \mathrm{O}$ flux & 1.00 & 0.03 & 0.36 & $0.88^{* *}$ \\
Denitrification & 0.03 & 1.00 & $0.50 *$ & -0.44 \\
Heterotrophic nitrification & 0.36 & $0.50 *$ & 1.00 & 0.05 \\
Autotrophic nitrification & $0.88^{* *}$ & -0.44 & 0.05 & 1.00 \\
\hline
\end{tabular}

*Correlation is significant at level 0.05

$* *$ Correlation is significant at level 0.01 


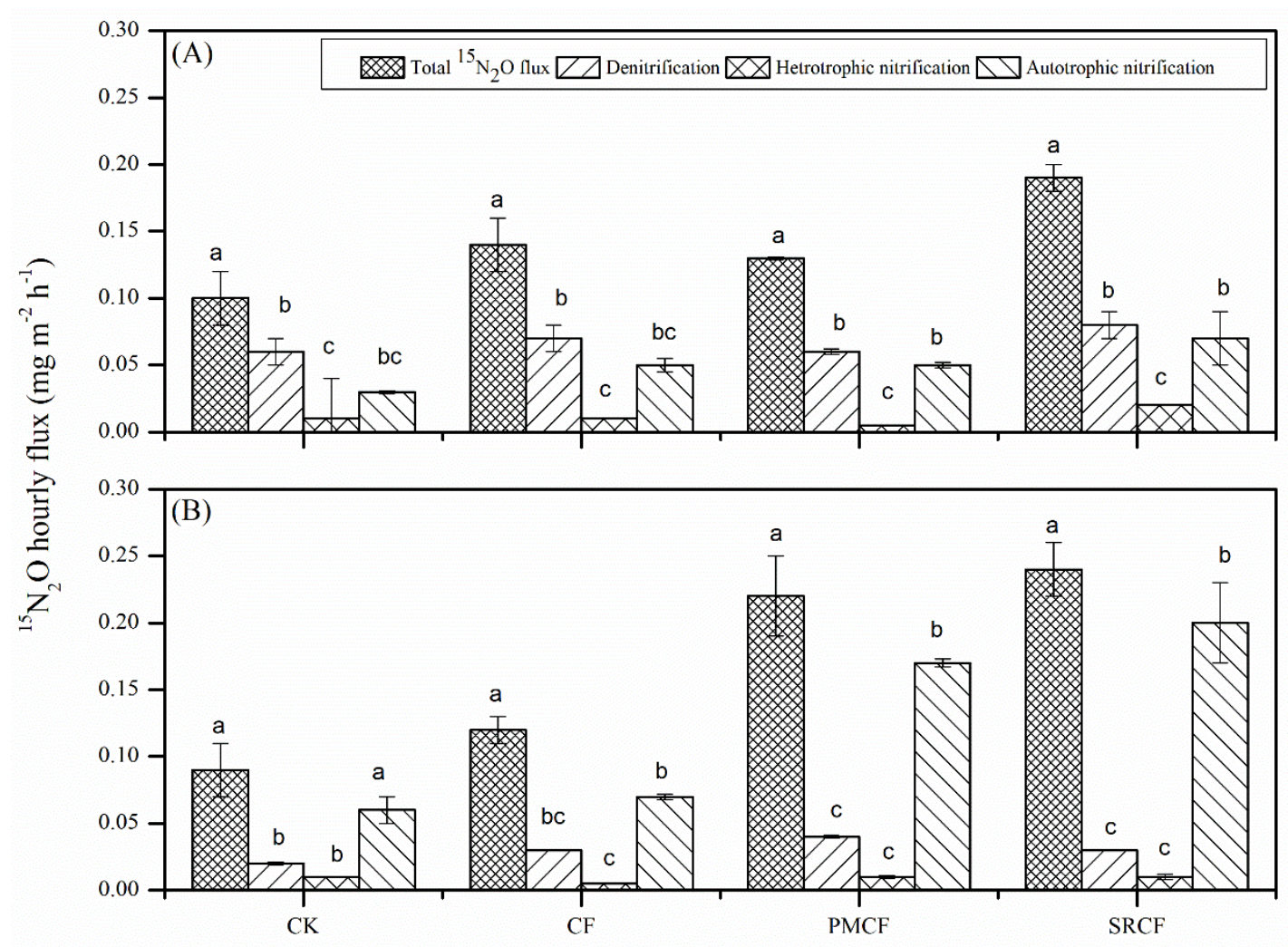

Figure 3. Hourly isotopic $\mathrm{N}_{2} \mathrm{O}$ emission $\left(\mathrm{mg} \mathrm{m}^{-2} \mathrm{~h}^{-1}\right)$ and the emission come from denitrification, heterotrophic and autotrophic nitrification from (A) $P F$ and (B) AWD conditions. Arrow bar represents standard deviation $(n=3)$. Different letters show significant differences among treatments $(P<0.05)$. CK: control, $C F$ : Chemical fertilization, PMCF: Pig manure plus chemical fertilizer, SRCF: Rice straw plus chemical fertilizer

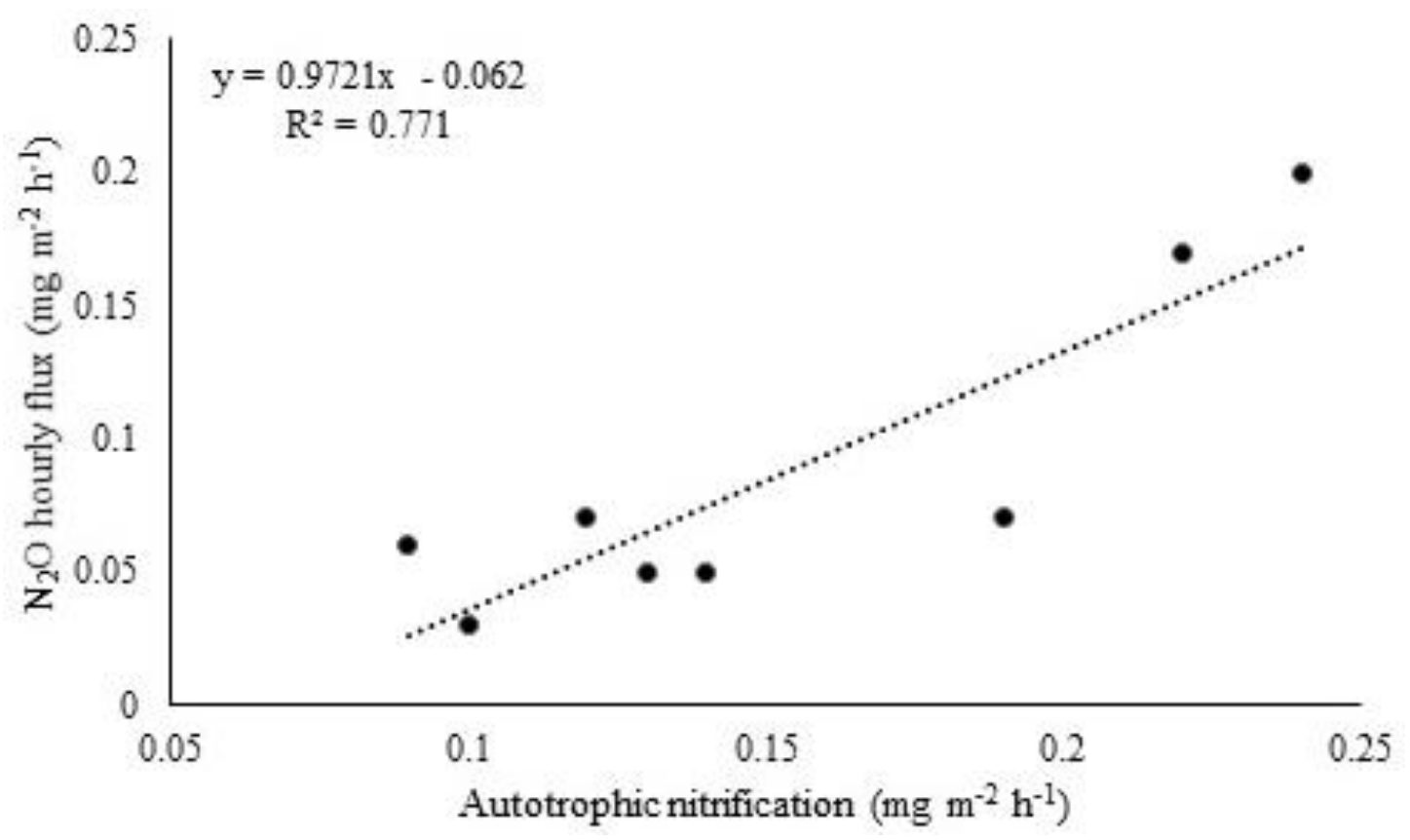

Figure 4. Correlation between total ${ }^{15} \mathrm{~N}_{2} \mathrm{O}$ emission and autotrophic nitrification 
Table 4. Mean hourly emission of ${ }^{14+15} \mathrm{~N}_{2} \mathrm{O}$ emission (mean \pm S.D), total and percentage (\%) contribution of denitrification, heterotrophic and autotrophic nitrification during AWD and PF events $(n=4)$

\begin{tabular}{c|c|c}
\hline & AWD & PF \\
\cline { 2 - 3 } & $\mathbf{6 0 \%} \mathbf{F C}, \mathbf{1 4} \mathbf{~ d}$ & Flooding, 14 d \\
\hline Total ${ }^{\mathbf{1 4 + 1 5}} \mathbf{N}_{\mathbf{2}} \mathbf{O}$ emission $\left(\mathbf{m g ~ m}^{-\mathbf{2}} \mathbf{h}^{-\mathbf{1}}\right)$ & & \\
\hline${ }^{14} \mathrm{~N}_{2} \mathrm{O}$ hourly flux & $0.89 \pm 0.22$ & $0.15 \pm 0.01$ \\
${ }^{15} \mathrm{~N}_{2} \mathrm{O}$ hourly flux & $0.16 \pm 0.06$ & $0.13 \pm 0.03$ \\
\hline Contributing processes $\left(\mathbf{m g ~ m}^{\mathbf{2}} \mathbf{h}^{\mathbf{- 1}}\right)$ & & \\
\hline Denitrification & $0.03 \pm 0.01(16.12 \%)$ & $0.07 \pm 0.01(52.88 \%)$ \\
Heterotrophic nitrification & $0.01 \pm 0.00(5.16 \%)$ & $0.01 \pm 0.01(10.57 \%)$ \\
Autotrophic nitrification & $0.12 \pm 0.06(79.03 \%)$ & $0.05 \pm 0.01(36.53 \%)$ \\
\hline
\end{tabular}

AWD: alternate wetting and drying, PF: permanent flooding

\section{Abundance of nitrifier and denitrifier}

The AOA amoA gene abundance was found in the range of $2.16 \mathrm{E}+06-1.61 \mathrm{E}+08$ copies $\mathrm{g}^{-1}$ of the soil (Fig. 5). The copy numbers increased with time during both AWD and PF events. The AOA amoA gene abundance was found significantly higher at $60 \%$ FC (14 days) in the CK, PMCF and SRCF $(P<0.0001)$. While, during PF, PMCF only increased AOA amoA gene abundance, especially after 10 days and 14 days.

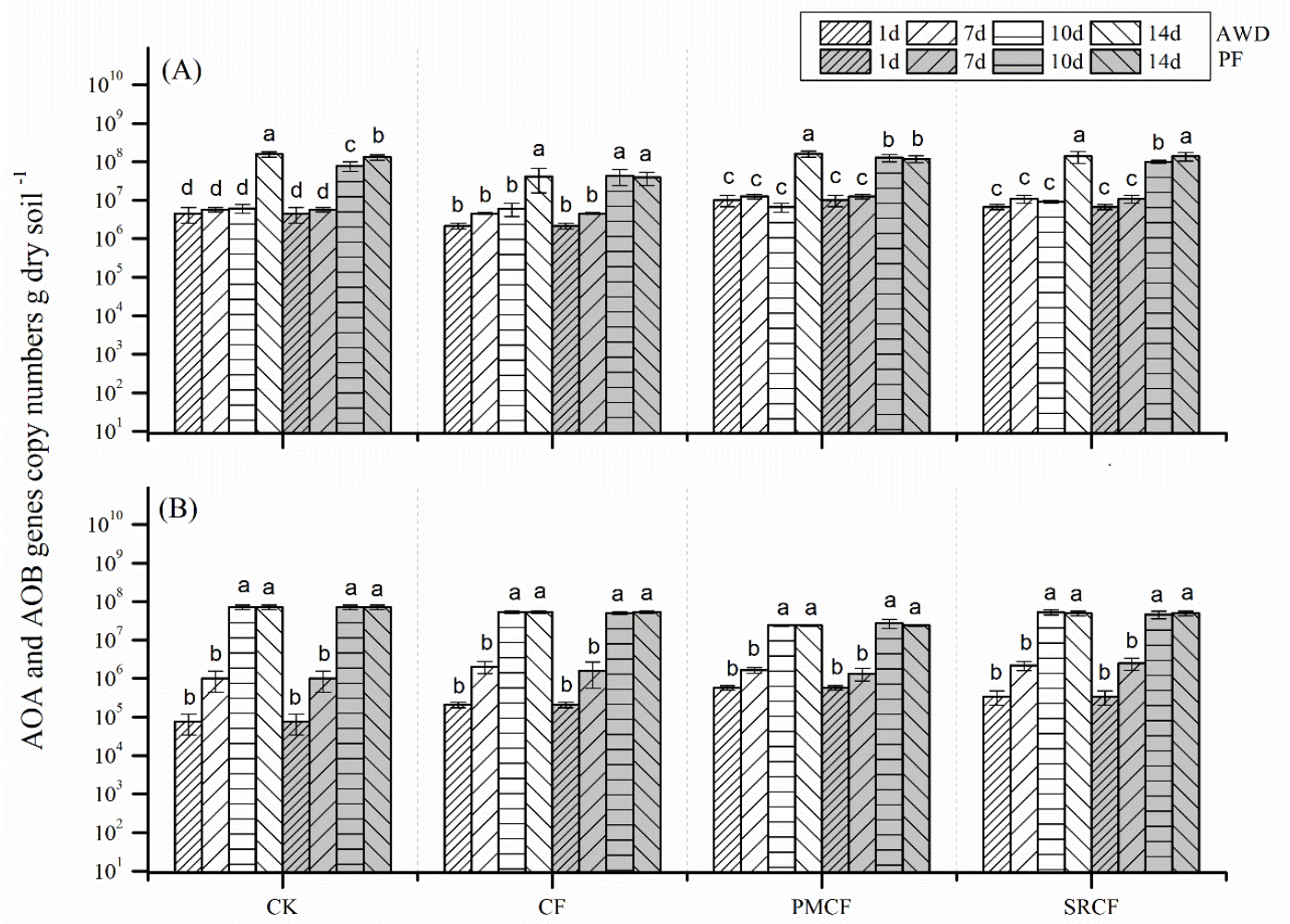

Figure 5. Abundance of (A) AOA and (B) AOB gene (copy numbers $g$ dry soil ${ }^{-1}$ ) after $1,7,10$ and 14 days of incubation during $A W D$ and $P F$ events. $A W D$ represents alternate drying and flooding conditions while PF represents permanent flooding conditions. Arrow bar above the line shows standard deviation $(n=3, P<0.0001)$. CK: control, CF: Chemical fertilization, PMCF: Pig manure plus chemical fertilizer, SRCF: Rice straw plus chemical fertilizer 
The AOB amoA gene abundance was found in the range of $7.68 \mathrm{E}+04-7.13 \mathrm{E}+07$ copy numbers $\mathrm{g}^{-1}$ of dry soil, with the highest value at $60 \%$ FC (14 days) in CK and CF treatments (Fig. 5). While, during AWD, a gradual increase in copy numbers were noted with time and relatively high at $80 \%$ FC and $60 \%$ FC. Also, during PF, this increase in copy numbers were recorded with time in all treatments. It was interesting that significant increases in copy numbers were found in $\mathrm{CK}$ and $\mathrm{CF}$ treatments during early stages $(P<0.0001)$. After $14 \mathrm{~d}$, significant differences were noted between treatments.

The abundance of the nirS gene significantly increased with time during both water events. Significant differences were found among treatments during the later stage of experiment $(P<0.0001)$. During PF event, this increase in copy numbers were in certain limit and after that it started to decrease or remain constant. Moreover, relatively higher gene abundances were found in PMCF and SRCF during the whole trial period during both water events.

Although the abundance of nirK gene varied with time under all moisture conditions i.e. $60 \% \mathrm{FC}$ and $100 \%$ FC. The high genes abundance was found during flooded condition in all treatments but relatively higher abundance was in PMCF treatment (Fig. 6). The highest value $(6.94 \mathrm{E}+06)$ of $n i r \mathrm{~K}$ was observed in the PMCF treatment after 14 days of PF.

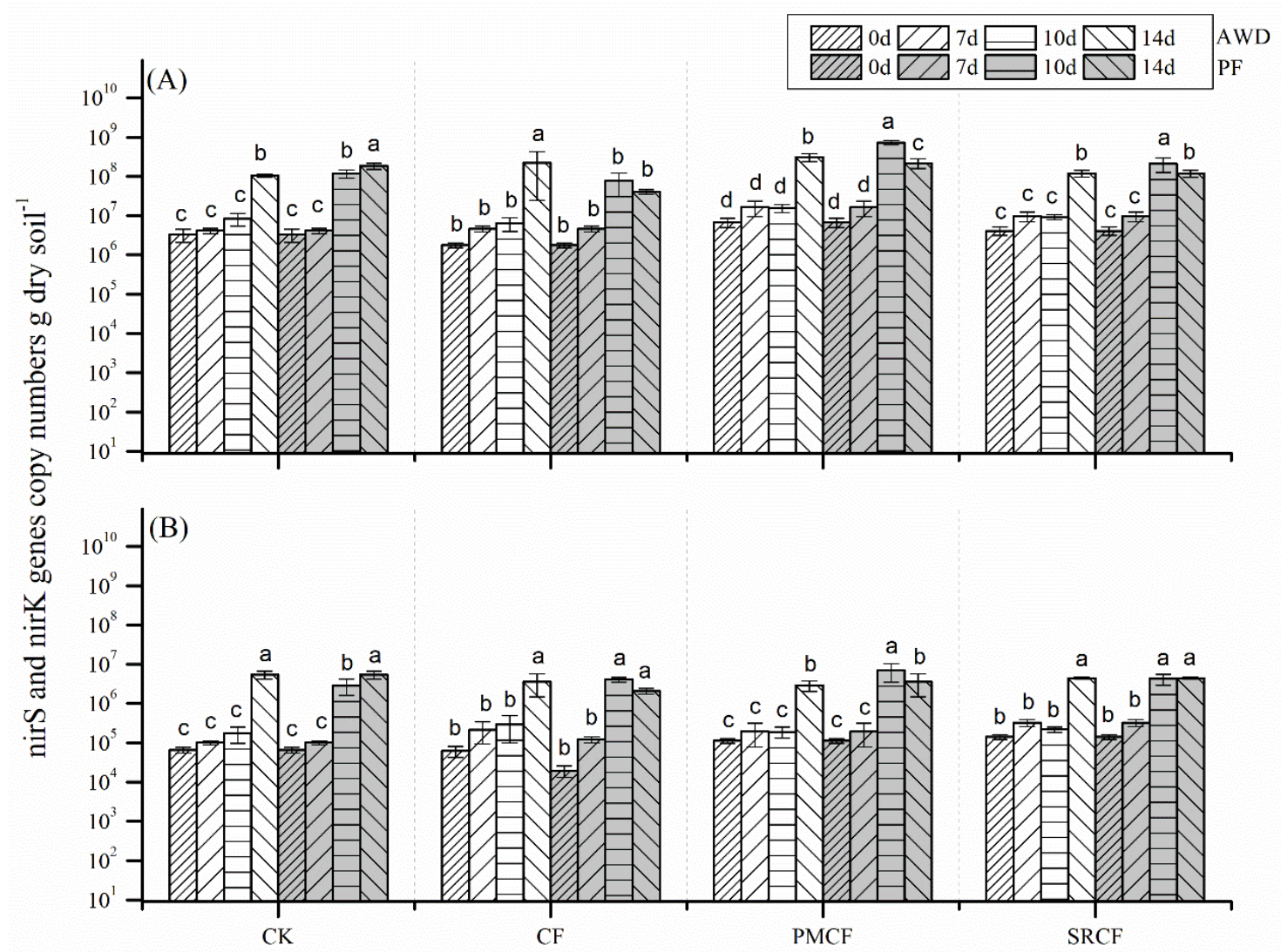

Figure 6. Abundance of (A) nirS and (B) nirK genes (copy numbers $g$ dry soil ${ }^{-1}$ ) after $1,7,10$ and 14 days of incubation during $A W D$ and $P F$ events. $A W D$ represents alternate drying and flooding conditions while PF represents permanent flooding conditions. Arrow bar above the line shows standard deviation ( $n=3, P<0.0001)$. CK: control, $C F$ : Chemical fertilization, PMCF: Pig manure plus chemical fertilizer, SRCF: Rice straw plus chemical fertilizer 


\section{Proportion of greenhouse gases emission associated with microbial biomass and water condition}

The relationship of nitrifiers and denitrifiers with $\mathrm{N}_{2} \mathrm{O}$ emissions under AWD and PF conditions are given in Table 5. A significant correlation was observed between AOB and $\mathrm{N}_{2} \mathrm{O}$ emissions during both $\mathrm{AWD}$ and $\mathrm{PF}$, suggesting that $\mathrm{AOB}$ is responsible for $\mathrm{N}_{2} \mathrm{O}$ emissions whatever the water events are (AWD or PF). The correlation between $\mathrm{N}_{2} \mathrm{O}$ and nitrifiers and denitrifiers suggested that $\mathrm{N}_{2} \mathrm{O}$ emissions is mainly affected by AOB.

Table 5. Correlation between $\mathrm{N}_{2} \mathrm{O}, A O A, A O B$ and nirK genes $(n=24)$

\begin{tabular}{c|c|c|c|c|c}
\hline & $\mathbf{N}_{2} \mathbf{O}$ & AOA & AOB & nir $\mathbf{~}$ & nirK \\
\hline $\mathrm{N}_{2} \mathrm{O}$ & 1.00 & $-0.96^{* *}$ & $0.54^{*}$ & 0.11 & $0.92^{* *}$ \\
$\mathrm{AOA}$ & $-0.96^{* *}$ & 1.00 & -0.36 & -0.29 & $-0.81^{* *}$ \\
$\mathrm{AOB}$ & $0.54^{*}$ & -0.36 & 1.00 & 0.01 & $0.81^{* *}$ \\
nir $\mathrm{S}$ & 0.11 & -0.29 & 0.01 & 1.00 & 0.01 \\
nirK & $0.92^{*}$ & $-0.81^{* *}$ & $0.81^{* *}$ & 0.01 & 1.00 \\
\hline
\end{tabular}

*Correlation is significant at level 0.05 (two tail test)

**Correlation is significant at level 0.01 (two tail test)

\section{Discussion}

\section{Effect of moisture contents on $\mathrm{N}_{2} \mathrm{O}$ emissions}

A plethora of previous literature have described the significant changes in $\mathrm{N}_{2} \mathrm{O}$ emissions during alternate flooding and air drying events in paddy fields (Toyoda et al., 2011; Nishimura et al., 2011). AWD generally promotes $\mathrm{N}_{2} \mathrm{O}$ emissions compared to PF in most of studies (Prieme and Christensen, 2001; Wu et al., 2017; Zou et al., 2005; Hou et al., 2012). Although, significant higher $\mathrm{N}_{2} \mathrm{O}$ fluxes were observed when the water was removed from the all treatments $(10 \mathrm{~d}, 14 \mathrm{~d})$, confirmed by earlier findings (Toyoda et al., 2011; Nishimura et al., 2004, 2011). Jorgensen et al. (1998) and Scholes et al. (1997) have reported a rise in $\mathrm{N}_{2} \mathrm{O}$ flux during AWD after submerged conditions, and these results were due to the combined effect of high microbial activity and escape of entrapped $\mathrm{N}_{2} \mathrm{O}$ (Rice and Smith, 1982). Moreover, the $\mathrm{N}_{2} \mathrm{O}$ emissions in PMCF, SRCF and CF treatments were greater than control (CK) suggesting that the application of long-term inorganic or organic fertilizers increase $\mathrm{N}_{2} \mathrm{O}$ productions during soil drying-rewetting events (Fig. 2). This high $\mathrm{N}_{2} \mathrm{O}$ emission in the PMCF and SRCF might be due to the high concentration of organic $\mathrm{N}$ fertilizer in the PMCF and SRCF. In this study, $\mathrm{N}_{2} \mathrm{O}$ fluxes were positively affected by fertilization (CF, PMCF, and SRCF). Similar results were reported in previous studies conducted in rice paddies (Hou et al., 2012; Zou et al., 2005) presenting that fertilization had a noticeable effect on $\mathrm{N}_{2} \mathrm{O}$ emissions because majority of inorganic $\mathrm{N}$ is supplied by fertilization in the form of $\mathrm{NH}_{4}{ }^{+}-\mathrm{N}$ and $\mathrm{NO}_{3}{ }^{-} \mathrm{N}$, which promotes $\mathrm{N}_{2} \mathrm{O}$ production (Liu et al., 2015). Harrison-Kirk et al. (2013) revealed $\mathrm{N}_{2} \mathrm{O}$ fluxes increased exponentially by increasing $\mathrm{C}$ up to $50 \mathrm{mg} \mathrm{g}^{-1}$ soil by organic fertilizer application. It is interesting that $\mathrm{N}_{2} \mathrm{O}$ fluxes always showed the following order: $\mathrm{CK}<\mathrm{CF}<\mathrm{PMCF}<\mathrm{SRCF}$ during whole trial period. 


\section{Effect of water conditions on nitrifier and denitrifier abundance based on long term fertilization}

AOA abundance in our results was more dominant compared to AOB, which was consistent with previous studies (He et al., 2007; Alam et al., 2013). This increase in AOA compared to the abundance of AOB might be due to high AOA affinity for oxygen (Szukics et al., 2009). However, Soil pH is another sole factor which may increase AOA abundance, producing favorable conditions for AOA in the paddy fields. Meanwhile, AOB abundance was mainly increased by $\mathrm{pH}$ (Nicol et al., 2008). In addition, some previous studies revealed that fertilization rate is the main driver of AOB and AOA abundances to decrease or remain unaffected (Zhong et al., 2016; Di et al., 2014). Also, the influence of fertilizer application on AOA and AOB were reported in some other filed studies (Dai et al., 2013; Alam et al., 2013) and laboratory incubation (Di et al., 2009). $\mathrm{NH}_{4}^{+}$availability produced by organic nitrogen mineralization or either by added inorganic $\mathrm{NH}_{4}{ }^{+}$is the sole factor responsible for the abundance of AOA and AOB (Tourna et al., 2008). However, the $\mathrm{pH}$ might influence $\mathrm{NH}_{4}{ }^{+}$availability because under low $\mathrm{pH}$ it would be ionized to $\mathrm{NH}_{4}{ }^{+}$(Nicol et al., 2008; He et al., 2007). Therefore, in the rice paddies, the drop of soil $\mathrm{pH}$ by fertilization, was a more significant factor to increase the availability of substrate for AOA.

The abundances of nirK and nirS genes had dramatically increased with time after 7 days in AWD and in PF until 10 days and then maintained or decreased (after 14 days). These results were in agreement with previous study of Uchida et al. (2014), indicated that under the absolute anaerobic conditions, the denitrifier abundance was reduced. In addition, the denitrifier abundance was influenced by flooding-drying pattern because denitrifier growth usually stimulate near anaerobic conditions (Uchida et al., 2014; Di et al., 2014). Alternatively, Cui et al. (2016) recognized a notable increase in denitrifiers abundance (nirK, nirS) after long-term fertilization which is similar to our results in which the abundance of denitrifiers were found high in PMCF and SRCF treatments. Hamonts et al. (2013) reported that dissolved organic carbon (DOC), $\mathrm{NO}_{3}{ }^{-}$and $\mathrm{NO}_{2}{ }^{-}$might increase denitrifiers copy numbers in fertilized soils. Moreover, low $\mathrm{pH}$ is recognized to reduce the assembly and turnover of $\mathrm{N}_{2} \mathrm{O}$ reductase (Bergaust et al., 2010). In a recent study, DOC and $\mathrm{NO}_{3}{ }^{-}$contents increased by fertilization could decrease soil $\mathrm{pH}$ (data not shown). Together, these factors might have led to a neutral effect on the denitrifiers abundances.

\section{Contribution of nitrification and denitrification on $\mathrm{N}_{2} \mathrm{O}$ emissions with respect to water conditions}

Nitrous oxide in soil are produced by various $\mathrm{N}$ transformation processes, i.e. nitrification (heterotrophic or autotrophic) and denitrification (Ruser et al., 2006; Beare et al., 2009; Hayakawa et al., 2009). However, in rice paddy soil, the water contents and fertilization rate are the main drivers for particular $\mathrm{N}$ transformation process. According to our results, the main contributor to $\mathrm{N}_{2} \mathrm{O}$ production was autotrophic nitrification at $60 \%$ FC while denitrification was the predominant source during PF, consistent with Bateman and Baggs (2005). It is interesting that denitrification and autotrophic nitrification produce equally in PMCF and SRCF treatments during PF events and this relation is not significant however in $\mathrm{CK}$ and $\mathrm{CF}$ this relation was significant. The predominant contribution of autotrophic nitrification might be due to favorable conditions for substrate and $\mathrm{O}_{2}$ diffusion. Similarly, autotrophic nitrification contributed 
equally during PF because it proceeds under limited short-term $\mathrm{O}_{2}$ during process of nitrifier denitrification (Poth and Focht, 1985; Goreau et al., 1980; Wrage et al., 2001 Bollmann and Conrad, 1998). In addition, nitrifier denitrification at higher water level might be another reason of high autotrophic nitrification contribution (Bollmann and Conrad, 1998). Alternatively, at high concentration of $200 \mathrm{~kg} \mathrm{~N} \mathrm{ha}{ }^{-1} \mathrm{NH}_{4} \mathrm{NO}_{3}$ $\left(>10 \mu \mathrm{g} \mathrm{g}^{-1}\right.$ ) inhibited the conversion of $\mathrm{N}_{2} \mathrm{O}$ to $\mathrm{N}_{2}$ for a limited time because $\mathrm{NO}_{3}{ }^{-}$is more suitable electron acceptor over $\mathrm{N}_{2} \mathrm{O}$ (Blackmer and Bremner, 1978). Although, a very low heterotrophic nitrification contribution was observed during both water events, and this might be due to a limited $\mathrm{C}$ and $\mathrm{O}_{2}$ availability for heterotrophic nitrification or that $\mathrm{N}_{2} \mathrm{O}$ emission during heterotrophic nitrification process was unable to be detected (Bateman and Baggs, 2005). I has been assumed that both denitrification and nitrification processes had contribution to $\mathrm{N}_{2} \mathrm{O}$ emission at $60 \%$ FC. In addition, the contribution of nitrification in fertilization treatments was higher than denitrification because fertilization always promotes nitrification in the soil.

\section{Conclusions}

Rewetting and drying conditions had an important impact on $\mathrm{N}_{2} \mathrm{O}$ emissions, growth of denitrifier and nitrifier communities along the experiment. However, denitrifier and ammonia oxidizer growth (AOA, AOB, nirS, nirK) were significantly affected by soil moisture contents. Meanwhile, AWD event promoted $\mathrm{N}_{2} \mathrm{O}$ fluxes compared to PF. PMCF and SRCF increased $\mathrm{N}_{2} \mathrm{O}$ emissions during both water events (AWD, PF). After finding out the dominant contributor it had been evaluated that autotrophic nitrification had a dominant role in both AWD and PF conditions. Moreover, a significant correlation between the $\mathrm{N}_{2} \mathrm{O}$ emission and AOB copy numbers were found in different wetting-drying conditions, showing that $\mathrm{AOB}$ has dominant role in $\mathrm{N}_{2} \mathrm{O}$ emission by the process of nitrification. Thus present study emphasizes that the PF water conditions are the better option to mitigate nitrous oxide form terrestrial environment to atmospheric environment. However, further study needed to emphasize the underlying process of nitrous oxide emissions.

Acknowledgments. The authors gratefully acknowledge the financial support of The National Natural Science Foundation of China (41877044), The National Key Basic Research Program of China (2015CB150502), The National Key Research and Development Program of China (2016YFD0801103) and Hangzhou Science and Technology Bureau Project (179464).

\section{REFERENCES}

[1] Abbasi, M. K., Adams, W. A. (2000): Gaseous N emission during simultaneous nitrification-denitrification associated with mineral $\mathrm{N}$ fertilisation to a grassland soil under field conditions. - Soil Biol. Biochem. 32: 1251-1259.

[2] Abid, A. A., Zhang, Q. C., Wang, J. W., Di, H. J. (2018): Nitrous Oxide fluxes and nitrifier and denitrifier communities as affected by dry-wet cycles in long term fertilized paddy soils. - Appl. Soil Eco. 125: 81-87.

[3] Alam, M. S., Ren, G. D., Lu, L., Zheng, Y., Peng, X. H., Jia, Z. J. (2013): Conversion of upland to paddy field specifically alters the community structure of archaeal ammonia oxidizers in an acid soil. - Biogeosciences 10: 5739-5753. 
[4] Baggs, E. M., Richter, M., Cadisch, G., Hartwig, U. A. (2003): Denitrification in grass swards is increased under elevated atmospheric $\mathrm{CO}_{2}$. - Soil Biol. Biochem. 35: 729-732.

[5] Bateman, E. J., Baggs, E. M. (2005): Contributions of nitrification and denitrification to $\mathrm{N}_{2} \mathrm{O}$ emissions from soils at different water-filled pore space. - Biol. Fert. Soils. 41(6): 379-388.

[6] Beare, M. H., Gregorich, E. G., Georges, P. S. (2009): Compaction effects on $\mathrm{CO}_{2}$ and $\mathrm{N}_{2} \mathrm{O}$ production during drying and rewetting of soil. - Soil Biol. Biochem. 41(3): 611621.

[7] Belder, P., Bouman, B. A. M., Cabangon, R., Guoan, L., Quilang, E. J. P., Yuanhua, L., Spiertz, J. H. J., Tuong, T. P. (2004): Effect of water-saving irrigation on rice yield and water use in typical lowland conditions in Asia. - Agricultural Water Management 65: 193-210.

[8] Berg, P., Klemedtsson, L., Rosswall, T. (1982): Inhibitory effect of low partial pressures of acetylene on nitrification. - Soil Biol. Biochem. 14: 301-303.

[9] Bergaust, L., Mao, Y., Bakken, L. R., Frostegard, A. (2010): Denitrification response patterns during the transition to anoxic respiration and posttranscriptional effects of suboptimal $\mathrm{pH}$ on nitrogen oxide reductase in Paracoccus denitrificans. - Appl. Environ. Microb. 76: 6387-6396.

[10] Blackmer, A. M., Bremner, J. M. (1978): Inhibitory effect of nitrate on reduction of $\mathrm{N}_{2} \mathrm{O}$ to $\mathrm{N}_{2}$ by soil microorganisms. - Soil Biol. Biochem. 10: 187-191.

[11] Bollmann, A., Conrad, R. (1998): Influence of $\mathrm{O}_{2}$ availability on $\mathrm{NO}$ and $\mathrm{N}_{2} \mathrm{O}$ release by nitrification and denitrification in soils. - Global Change Bio. 4: 387-396.

[12] Cabangon, R. J., Tuong, T. P., Castillo, E. G., Bao, L. X., Lu, G., Wang, G., Cui, Y., Bouman, B. A. M., Li, Y., Chen, C., Wang, J. (2004): Effect of irrigation method and Nfertilizer management on rice yield, water productivity and nutrient-use efficiencies in typical lowland rice conditions in China. - Paddy and Water Environment 2: 195-206.

[13] Carrijo, D. R., Lundy, M. E., Linquist, B. A. (2017): Rice yields and water use under alternate wetting and drying irrigation: a meta-analysis. - Field Crops Res. 203: 173-180.

[14] Chapagain, T., Yamaji, E. (2010): The effects of irrigation method, age of seedling and spacing on crop performance, productivity and water-wise rice production in Japan. Paddy Water Environ. 8: 81-90.

[15] Charles, A., Rochette, P., Whalen, J. K., Angers, D. A., Chantigny, M. H., Bertrand, N. (2017): Global nitrous oxide emission factors from agricultural soils after addition of organic amendments: a meta-analysis. - Agric. Ecosyst. Environ. 236: 88-98. https://doi.org/10.1016/j.agee.2016.11.021.

[16] Cui, P., Fan, F., Yin, C., Song, A., Huang, P., Tang, Y., Zhu, P., Peng, C., Li, T., Wakelin, S. A., Liang, Y. (2016): Long-term organic and inorganic fertilization alters temperature sensitivity of potential $\mathrm{N}_{2} \mathrm{O}$ emissions and associated microbes. - Soil Biol. Biochem. 93: 131-141.

[17] Dai, Y., Di, H. J., Cameron, K. C., He, J. Z. (2013): Effects of nitrogen application rate and a nitrification inhibitor dicyandiamide on ammonia oxidizers and $\mathrm{N}_{2} \mathrm{O}$ emissions in a grazed pasture soil. - Sci. Total Environ. 465: 125-135.

[18] Daum, M., Zimmer, W., Papen, H., Kloos, K., Nawrath, K., Bothe, H. (1998): Physiological and molecular biological characterization of ammonia oxidation of the heterotrophic nitrifier Pseudomonas putida. - Curr. Microbiol. 37: 281-288.

[19] Di, H. J., Cameron, K. C., Shen, J. P., Winefield, C. S., O'Callaghan, M., Bowatte, S., He, J. Z. (2009): Nitrification driven by bacteria and not archaea in nitrogen-rich grassland soils. - Nature Geoscience 2: 621-624.

[20] Di, H. J., Cameron, K. C., Podolyan, A., Robinson, A. (2014): Effect of soil moisture status and a nitrification inhibitor, dicyandiamide, on ammonia oxidizer and denitrifier growth and nitrous oxide emissions in a grassland soil. - Soil Biol. Biochem. 73: 59-68. 
[21] Garrido, F., Hénault, C., Gaillard, H., Pérez, S., Germon, J. C. (2002): $\mathrm{N}_{2} \mathrm{O}$ and NO emissions by agricultural soils with low hydraulic potentials. - Soil Biol. Biochem. 34: 559-575.

[22] Goreau, T. J., Kaplan, W. A., Wofsy, S. C., McElroy, M. B., Valois, F. W., Watson, S. W. (1980): Production of $\mathrm{NO}_{2}{ }^{-}$and $\mathrm{N}_{2} \mathrm{O}$ by nitrifying bacteria at reduced concentrations of oxygen. - Appl. Environ. Microbiol. 40: 526-532.

[23] Hamonts, K., Balaine, N., Moltchanova, E., Beare, M., Thomas, S., Wakelin, S. A., O'Callaghan, M., Condron, L. M., Clough, T. J. (2013): Influence of soil bulk density and matric potential on microbial dynamics inorganic $\mathrm{N}$ transformations, $\mathrm{N}_{2} \mathrm{O}$ and $\mathrm{N}_{2}$ fluxes following urea deposition. - Soil Biol. Biochem. 65: 1-11.

[24] Harrison-Kirk, T., Beare, M. H., Meenken, E. D., Condron, L. M. (2013): Soil organic matter and texture affect responses to dry/wet cycles: effects on carbon dioxide and nitrous oxide emissions. - Soil Biol. Biochem. 57: 43-55.

[25] Hayakawa, A., Akiyama, H., Sudo, S., Yagi, K. (2009): $\mathrm{N}_{2} \mathrm{O}$ and NO emissions from Andisol field as influenced by pelleted poultry manure. - Soil Biol. Biochem. 41(3): 521529.

[26] He, J., Shen, J., Zhang, L., Zhu, Y., Zheng, Y., Xu, M., Di, H. (2007): Quantitative analyses of the abundance and composition of ammonia-oxidizing bacteria and ammonia oxidizing archaea of a Chinese upland red soil under long-term fertilization practices. Environ. Microbiol. 9: 2364-2374.

[27] Hou, H., Peng, S., Xu, J., Yang, S., Mao, Z. (2012): Seasonal variations of $\mathrm{CH}_{4}$ and $\mathrm{N}_{2} \mathrm{O}$ emissions in response to water management of paddy fields located in Southeast China. Chemosphere 89: 884-892.

[28] Hynes, R. K., Knowles, R. (1982): Effect of acetylene on autotrophic and heterotrophic nitrification. - Can. J. Microbiol. 28: 334-340.

[29] IPCC (2007): Climate Change: The Physical Science Basis. - In: Solomo, S., Qin, D., Manning, M., et al. (eds.) Contribution of Working Group I to the Fourth Assessment Report of the Intergovernmental Panel on Climate Change (IPCC). Cambridge University Press, Cambridge.

[30] IPCC (2013): Summary for Policymakers. - In: Stocker, T. F., Qin, D., Plattner, G. K., Tignor, M., Allen, S. K., Boschung, J., Nauels, A., Xia, Y., Bex, V., Midgley, P. M. (eds.) Climate Change 2013: The Physical Science Basis. Contribution of Working Group I to the Fifth Assessment Report of the Intergovernmental Panel on Climate Change. Cambridge University Press, Cambridge, UK, New York. https://www.ipcc.ch/pdf/assessment-report/ar5/wg1/WGIAR5_SPM_brochure_en.pdf.

[31] Jorgensen, R. N., Jorgensen, B. J., Nielsen, N. E. (1998): $\mathrm{N}_{2} \mathrm{O}$ emission immediately after rainfall in a dry stubble field. - Soil Biol. Biochem. 30: 545-546.

[32] Liu, C., Yao, Z., Wang, K., Zheng, X. (2015): Effects of increasing fertilization rates on nitric oxide emission and nitrogen use efficiency in low carbon calcareous soil. - Agr. Ecosys. Environ. 203: 83-92.

[33] Liu, R., Hayden, H. L., Suter, H., Hu, H., Lam, S. K., He, J. (2017): The effect of temperature and moisture on the source of $\mathrm{N} 2 \mathrm{O}$ and contributions from ammonia oxidizers in an agricultural soil. - Biol Fertil. Soils. 53: 141-152. https://doi.org/10.1007/s00374-016-1167-8.

[34] Moir, J. W. B., Crossman, L. C., Spiro, S., Richardson, D. J. (1996): The purification of ammonia monooxygenase from Paracoccus denitrificans. - FEMS Lett. 387: 71-74.

[35] Nicol, G. W., Leininger, S., Schleper, C., Prosser, J. I. (2008): The influence of soil pH on the diversity, abundance and transcriptional activity of ammonia oxidizing archaea and bacteria. - Environ. Microbiol. 10: 2966-2978.

[36] Nishimura, S., Sawamoto, T., Akiyama, H., Sudo, S., Yagi, K. (2004): Methane and nitrous oxide emissions from a paddy field with Japanese conventional water management and fertilizer application. - Global Biogeochem. Cycles 18: GB2017. 
[37] Nishimura, S., Akiyama, H., Sudo, S., Fumoto, T., Cheng, W. G., Yagi, K. (2011): Combined emission of $\mathrm{CH}_{4}$ and $\mathrm{N}_{2} \mathrm{O}$ from a paddy field was reduced by preceding upland crop cultivation. - Soil Sci. Plant Nutr. 57: 167-178.

[38] Ostrom, N. E., Hedin, L. O., von Fischer, J. C., Robertson. G. P. (2002): Nitrogen transformations and nitrate removal at a soil-stream interface: a stable isotope approach. Ecological Applications 12: 1027-43.

[39] Peng, S. Z., Hou, H. J., Xu, J. Z., Mao, Z., Abudu, S., Luo, Y. F. (2011): Nitrous oxide emissions from paddy fields under different water managements in southeast China. Paddy Water Environ. 9: 403-411.

[40] Poth, M., Focht, D. D. (1985): ${ }^{15} \mathrm{~N}$ kinetic analysis of $\mathrm{N}_{2} \mathrm{O}$ production by Nitrosomonas europaea an examination of nitrifier denitrification. - Appl. Environ. Microbiol. 49: 1134-1141.

[41] Prieme, A., Christensen, S. (2001): Natural perturbations, drying-wetting and freezingthawing cycles, and the emission of nitrous oxide, carbon dioxide and methane from farmed organic soils. - Soil Biol. Biochem. 33: 2083-2091.

[42] Rice, C. W., Smith, M. S. (1982): Denitrification in no-till and plowed soils. - Soil Sci. Sot. Am. J. 46: 1168-1 173.

[43] Ruser, R., Flessa, H., Russow, R., Schmidt, G., Buegger, F., Munch, J. C. (2006): Emission of $\mathrm{N}_{2} \mathrm{O}, \mathrm{N}_{2}$ and $\mathrm{CO}_{2}$ from soil fertilized with nitrate: Effect of compaction, soil moisture and rewetting. - Soil Biol. Biochem. 38(2): 263-274.

[44] Scholes, M. C., Martin, R., Scholes, R. J., Parsons, D., Winstead, E. (1997): NO and $\mathrm{N}_{2} \mathrm{O}$ emissions from savanna soils following the first simulated rains of the season. - Nutrient Cycling in Agro. Eco. Systems 48: 115-122.

[45] Stevens, R. J., Laughlin, R. J., Burns, L. C., Arah, J. R. M., Hood, R. C. (1997): Measuring the contributions of nitrification and denitrification to the flux of nitrous oxide from soil. - Soil Biol. Biochem. 29: 139-151.

[46] Szukics, U., Hackl, E., Zechmeister-Boltenstern, S., Sessitsch, A. (2009): Contrasting response of two forest soils to nitrogen input: rapidly altered $\mathrm{NO}$ and $\mathrm{N}_{2} \mathrm{O}$ emissions and nirK abundance. - Biol. Fert. Soils 45: 855-863.

[47] Tourna, M., Freitag, T. E., Nicol, G. W., Prosser, J. I. (2008): Growth, activity and temperature responses of ammonia-oxidizing archaea and bacteria in soil microcosms. Environ. Microbiol. 10: 1357-1364.

[48] Toyoda, S., Yano, M., Nishimura, S., Akiyama, H., Hayakawa, A., Koba, K., Sudo, S., Yagi, K., Makabe, A., Tobari, Y., Ogawa, N. O., Ohkouchi, N., Yamada, K., Yoshida, N. (2011): Characterization and production and consumption processes of $\mathrm{N}_{2} \mathrm{O}$ emitted from temperate agricultural soils determined via isotopomer ratio analysis. - Global Biogeochem Cycles 25: GB2008.

[49] Uchida, Y., Wang, Y., Akiyama, H., Nakajima, Y., Hayatsu, M. (2014): Expression of denitrification genes in response to a waterlogging event in a Fluvisol and its relationship with large nitrous oxide pulses. - FEMS Microbiol. Ecol. 88: 407-423.

[50] Webster, E. A., Hopkins, D. W. (1996): Contributions from different microbial processes to $\mathrm{N}_{2} \mathrm{O}$ emissions from soil under different moisture regimes. - Biol. Fertil. Soils 22: 331335 .

[51] Wrage, N., Velthof, G. L., van Beusichem, M. L., Oenema, O. (2001): Role of nitrifier denitrification in the production of nitrous oxide. - Soil Biol. Biochem. 33: 1723-1732.

[52] Wu, K., Chen, Z., Li, X., Xu, J., Li, J., Wang, K., Wang, H., Wang, S., Dong, X. (2017): Flow behavior of gas confined in nanoporous shale at high pressure: real gas effect. Fuel 205: 173-183.

[53] Zhang, X., Wong, M., Feng, X., Wang, K. (2009): Identification of soil heavy metal sources from anthropogenic activities and pollution assessment off fuyang County, China. - Environ. Monit. Assess. 154(1): 439-449.

[54] Zhong, W., Bian, B., Gao, N., Min, J., Shi, W., Lin, X., Shen, W. (2016): Nitrogen fertilization induced changes in ammonia oxidation are attributable mostly to bacteria 
rather than archaea in greenhouse-based high $\mathrm{N}$ input vegetable soil. - Soil Biol. Biochem. 93: 150-159.

[55] Zou, J. W., Huang, Y., Jiang, J. Y. (2005): A 3-year field measurement of methane and nitrous oxide emissions from rice paddies in China: effects of water regime, crop residue, and fertilizer application. - Glob Biogeochem. Cycles. DOI: 10.1029/2004 gb002401. 